\title{
ACTIVE LEARNING MODELS TECHNIQUES LEARNING START WITH A QUESTION TO INCREASE LIVELINESS OF STUDENTS
}

\section{MODEL ACTIVE LEARNING TEKNIK LEARNING STARTS WITH A QUESTION UNTUK MENINGKATKAN KEAKTIFAN SISWA}

\author{
Oleh: \\ Nurmawaddah \\ Accounting Education Study Program Yogyakarta State University \\ nurmawaddah944@gmail.com
}

\begin{abstract}
This research is a classroom action research.This study has the objective to increase liveliness of students' in accounting learning class XI Accounting 1 SMK Negeri 1 Yogyakarta Academic Year 2016/2017 use Active Learning Model Techniques Learning Start With A Question. As for the four stages including planning, implementation, observation, and reflection. The research data were collected through observations, documentation, and field notes. Improvement liveliness of students can be seen from the average liveliness of students in the first cycle showed $48.35 \%$ of the students have been active and average liveliness of students in the second cycle increased to $78.47 \%$. Increased liveliness of students from the first cycle to the second cycle amounted to $30.12 \%$.
\end{abstract}

Keywords : Learning Start With A Question, liveliness of students.

\section{Abstrak}

Penelitian ini adalah Penelitian Tindakan Kelas (Classroom Action Research). Penelitian ini memiliki tujuan untuk meningkatkan keaktifan belajar siswa pada pembelajaran akuntansi keuangan siswa kelas XI Akuntansi 1 SMK Negeri 1 Yogyakarta Tahun Ajaran 2016/2017 menggunakan Model Active Learning dengan Teknik Learning Start With A Question. Penelitian Tindakan Kelas memiliki empat tahapan, yaitu perencanaan, pelaksanaan, pengamatan, dan refleksi. Teknik Pengumpulan data dalam penelitian ini melalui obervasi, dokumentasi, dan catatan lapangan. Peningkatan Keaktifan Belajar Siswa tersebut dapat dilihat dari rata-rata kekatifan belajar siswa pada siklus I menunjukkan 48,35\% siswa telah aktif dan rata-rata keaktifan siswa pada siklus II meningkat menjadi 78,47\%. Peningkatan keaktifan belajar siswa dari siklus I ke skilus II sebesar 30,12\%.

Kata Kunci: Learning Start Wih A Question, Keaktifan siswa.

\section{INTRODUCTION}

Learning is a process of human interaction that characterized the balance between the sovereignty of students subject to the authority of educator. Learning activities occur when the students subject actively interact with a learning environment that is regulated by the teacher/ lecturer.

Badan Standar Nasional Pendidikan 2010 on the National XXI Century Paradigm of Education said that:

"The era of globalization and openness has changed the face of the world in many aspects of community life, one of them is in the field of education. The more rapid development of science and technology lead to more challenges and demands that must be passed by the actors of education. In the face of these challenges, then there was a change in the paradigm of education to appropriate the changes in this century. We need the human skills to quickly adjust themselves to change from passive to active, from simply memorizing be thinking, from individuals into a collaborative, from receiving something that already finished to produce something new. From the change of educational paradigm showed 
that the learning activities was be undertaken in education must be a student-centered, interactive, students should be active, critical and cooperative".

Based on the change of educational paradigm, then one appropriate learning methods to applied is active learning. Active learning is basically one type of learning approaches on action-oriented learners. Activity-oriented learning implies that learning system placing the student as active subjects and students who already have a readiness to learn. Based on the research by Elza Firanda Riswandi (2012) entitled "Model Active Learning dengan Teknik Learning Start With A Question untuk Meningkatkan keaktifan Peserta Didik pada Pembelajaran Akuntansi Kelas XI Ilmu Sosial 1 SMA Negeri 7 Yogyakarta Tahun Ajaran 2011/2012" that the Active Learning Model Techniques learning Start with A Question can enhance the activity of students in accounting learning. research conducted by Fitri Umiatun (2013) entitled "Penerapan Model Active Learning Teknik Learning Start With A Question (LSQ) Untuk Meningkatkan Keaktifan Belajar Siswa Pada Pembelajaran Akuntansi Kelas $X$ Akuntansi I SMK Negeri 1 Pengasih Tahun Ajaran 2012/2013" which concluded that the Active learning Model Techniques learning Start With A Question can improve students' learning activeness.

Based on observation's result in class XI Accounting 1 SMK Negeri 1 Yogyakarta, it can be seen that some students are passive in having the learning activities. Some students did not pay attention to the teacher's explanation, speak with friends, get sleepy, did not read course materials, and being less active in asking about the material which is being taught. Moreover, in terms of teaching methods and learning methods they are used less varied, teachers still apply the learning methods and applying teacher-centered approach that which is no involving students' participation. The learning process with the conventional method is not sufficient to provide a deep impression to the students because the role of the teacher in delivering the material is more dominant than the level of student activity.

The results of observation reinforced by testimony from teachers who claimed that during learning, the liveliness of the students in asking still lacking and also another liveliness that are supposed to be able to support the success of the learning process. Student activities have only limited application of the method used, that is exercises methods and tasks. Some teachers expressed that they have many seminars on a variety of methods and models of learning but the teacher has not been able to understand and apply it in the classroom. According to some students, there is a reluctance of students to ask to the teacher because of shame, fear, do not know, lazy and prefer to ask to their friend outside class hours.

Based on that case, these problems must be overcome using the right solution. The solution for the problems above is to do classroom action research. "Classroom action research is a scrutiny of learning activities in the form of an action, which is deliberately raised and occur within a class together" (Suharsimi Arikunto, 2011: 3). Classroom Action Research can be done with a lot of models. Teachers can use a new model of learning that has not previously been applied. One of the models that was be used in this research to increase the liveliness of Students in Accounting learning is Active Learning model. Active learning that can be used as an alternative model of learning and thought to correspond to the learning objectives, learning materials, and the condition of students is using the technique of Learning Start with a Question. This technique possible can increase active students in learning. Learning Start with A Question is a simple technique that can be applied to every situations of learning process and can provide a step for two-way communication 
between teachers and students, so as to inspire students to achieve key learning, that is ask questions.

The Action of active learning as mentioned above is done so that the students of class XI Accounting 1 SMK Negeri 1 Yogyakarta has the spirit of independence in learning and make grow their creativity so as to create new innovations, and is expected to be more active in expressing their opinions and work together, not only hear, read, and write what is presented by the teacher in accounting. Based on it, the researchers interested in conducting action research with the title "Active Learning Models using Technique Learning Start With A Question to Increase Liveliness of Students in Accounting Learning Class XI Accounting 1 SMK Negeri 1 Yogyakarta Academic Year 2016/2017".

\section{RESEARCH METHOD \\ Research Design}

This research is a classroom action research. Classroom Action Research must go through four stages. As for the four stages including planning, implementation, observation, and reflection.

\section{Location and Time of Research}

This research was conducted at SMK Negeri 1 Yogyakarta is located at Kemetiran Kidul Street, Pringgokusuman, Gedong Tengen, Yogyakarta, in class XI Accounting 1 in academic year 2016/2017. This research was be conducted from July to December 2016 which includes several stages of preparation, execution, and reporting.

\section{The Subject and Object of Research}

The subject of this research is class XI Accounting 1 SMK Negeri 1 Yogyakarta in academic year 2016/2017, amounting to 32 students. The object of this research is the liveliness of student in accounting learning class XI Accounting 1 SMK Negeri 1 Yogyakarta in Academic Year 2016/2017 through the implementation Active Learning models Techniques Learning Start With A Question.

\section{Research Procedure}

The research conducted in two cycle. Each cycle consist of four stages: planning stage, actuating stage, observation stage, and reflection stage. The cycle I and cycle II, the planning stage are make an agreement with accounting teacher for the materials to be used, making Lesson Plan, preparation of learning materials and exercises, arrange and prepare observation sheets on the participation of students in active learning techniques Learning Start With A Question, arrange format of daily event records to document the finding. The actuating stage consist of introduction, core, and closing. Techniques Learning Start With A Question is done in the following way: teachers choose reading materials in the form of appropriate materials and then distributed to students. Teachers shared reading material sought is material containing general information or readings that gives the opportunity to be interpreted differently. The teacher asks the students to learn reading alone or with their seatmate. While students read, the teacher asked the students to mark the passages that are not understood. Encourage them to mark as much as possible. The teacher asks the students to write down questions about the material they have read. Teachers encourage students to ask questions orally. Teachers offered to other students to answer questions from her friends and expressed her opinion about the answer. Teacher collects the questions that have been written by the students. Lastly, teachers delivering course material and answer the questions that have been collected but have not been answered or discussed by the students. The observation done by three observers. The observers observed the liveliness of students during the learning process using Active Learning Models Techniques Learning Start With A Question with the observation sheet and observation guidelines. 
Table 1. Guidelines for Assessment of Student Learning Activeness

\begin{tabular}{|c|c|c|}
\hline $\begin{array}{l}\mathbf{N} \\
\mathbf{0}\end{array}$ & Aspect & Indicators \\
\hline 1 & \multirow{2}{*}{$\begin{array}{l}\text { Visual } \\
\text { Live- } \\
\text { liness }\end{array}$} & Students read actively \\
\hline 2 & & $\begin{array}{l}\text { Students pay attention to } \\
\text { material explanation from the } \\
\text { teacher }\end{array}$ \\
\hline 3 & \multirow{3}{*}{$\begin{array}{l}\text { Oral } \\
\text { Live- } \\
\text { liness }\end{array}$} & $\begin{array}{l}\text { Students ask question to the } \\
\text { teacher or the class discussion } \\
\text { forum }\end{array}$ \\
\hline 4 & & $\begin{array}{l}\text { Students express their } \\
\text { opinions }\end{array}$ \\
\hline 5 & & $\begin{array}{l}\text { Students give answers to } \\
\text { excersice or question given } \\
\text { by the teacher }\end{array}$ \\
\hline 6 & \multirow{3}{*}{$\begin{array}{l}\text { Write } \\
\text { Live- } \\
\text { liness }\end{array}$} & $\begin{array}{l}\text { Students write and answer } \\
\text { questions that posed by } \\
\text { friends }\end{array}$ \\
\hline 7 & & Students do a given work \\
\hline 8 & & $\begin{array}{l}\text { Students make notes of } \\
\text { subject matter }\end{array}$ \\
\hline
\end{tabular}

(Source: adopted from Fitri Umiyatun, 2013: 73)

Table 2. Guidelines Scoring to Liveliness of the Student

\begin{tabular}{|l|c|}
\hline Active & 2 \\
\hline Quite Active & 1 \\
\hline Not Active & 0 \\
\hline
\end{tabular}

(Source: adopted from Fitri Umiyatun, 2013: 73)

\section{Data Collection Techniques and Research} Instrumen

a) Data

The research data were collected through observations, documentation, and field notes. The results of observations conducted by researcher is written in the observation sheet.

b) Data Collection Tecniques

The observation were used to collect data for three aspect that want to know the liveliness of students. That aspect are Visual Liveliness, Oral Liveliness, and Write Liveliness. Field note were used to collect data in this research by direct observation of activity in the classroom during the accounting learning process. Aspects that observed is an accounting learning process which designed to apply the technique Learning Start with A Question by observing the percentage of students who ask questions and do another activities actively at every session. Besides, documentation was also conducted during the learning takes place in the form of image capture is used to assist the process of reflection.

In this research, each aspect is successful when at least $75 \%$ of students participate actively (visual, verbal, and writing aspects $\geq 75 \%$, respectively). Total percentages obtained from every aspect then summed and divided by the number of existing aspects.

\section{FINDING AND DISCUSSION}

This study has the objective to increase liveliness of students' in accounting learning class XI Accounting 1 SMK Negeri 1 Yogyakarta Academic Year 2016/2017 use Active Learning Model Techniques Learning Start With A Question.

Table 3. The Result Assessment of Prestudy Learning Activeness Students

\begin{tabular}{|c|c|c|c|c|}
\hline \multirow[b]{2}{*}{$\begin{array}{c}\mathbf{N} \\
\mathbf{0}\end{array}$} & \multirow[b]{2}{*}{ Aspect } & \multirow[b]{2}{*}{ Indicators } & \multicolumn{2}{|c|}{ Percentage } \\
\hline & & & $\begin{array}{l}\text { Each } \\
\text { indi- } \\
\text { cator }\end{array}$ & $\begin{array}{l}\text { The } \\
\text { ave- } \\
\text { rage } \\
\text { each } \\
\text { as- } \\
\text { pect }\end{array}$ \\
\hline 1 & \multirow[b]{2}{*}{$\begin{array}{l}\text { Visual } \\
\text { Liveli- } \\
\text { ness }\end{array}$} & $\begin{array}{l}\text { Students } \\
\text { read } \\
\text { actively }\end{array}$ & $63 \%$ & \multirow[b]{2}{*}{$\begin{array}{c}48,4 \\
4 \%\end{array}$} \\
\hline 2 & & $\begin{array}{l}\text { Students } \\
\text { pay } \\
\text { attention to } \\
\text { material } \\
\text { explanation }\end{array}$ & $34 \%$ & \\
\hline
\end{tabular}




\begin{tabular}{|c|c|c|c|c|}
\hline \multirow{3}{*}{$\begin{array}{l}\mathbf{N} \\
\mathbf{0}\end{array}$} & \multirow{3}{*}{ Aspect } & \multirow[b]{2}{*}{ Indicators } & \multicolumn{2}{|c|}{ Percentage } \\
\hline & & & $\begin{array}{l}\text { Each } \\
\text { indi- } \\
\text { cator }\end{array}$ & $\begin{array}{l}\text { The } \\
\text { ave- } \\
\text { rage } \\
\text { each } \\
\text { as- } \\
\text { pect }\end{array}$ \\
\hline & & $\begin{array}{l}\text { from the } \\
\text { teacher }\end{array}$ & & \\
\hline 3 & \multirow{3}{*}{$\begin{array}{l}\text { Oral } \\
\text { Liveli- } \\
\text { ness }\end{array}$} & $\begin{array}{l}\text { Students } \\
\text { ask question } \\
\text { to the } \\
\text { teacher or } \\
\text { the class } \\
\text { discussion } \\
\text { forum }\end{array}$ & $25 \%$ & \multirow{3}{*}{$\begin{array}{c}24,5 \\
\%\end{array}$} \\
\hline 4 & & $\begin{array}{l}\text { Students } \\
\text { express } \\
\text { their } \\
\text { opinions }\end{array}$ & $11 \%$ & \\
\hline 5 & & $\begin{array}{l}\text { Students } \\
\text { give } \\
\text { answers to } \\
\text { excersice or } \\
\text { question } \\
\text { given by the } \\
\text { teacher }\end{array}$ & $38 \%$ & \\
\hline 6 & \multirow{3}{*}{$\begin{array}{l}\text { Write } \\
\text { Liveli- } \\
\text { ness }\end{array}$} & $\begin{array}{l}\text { Students } \\
\text { write and } \\
\text { answer } \\
\text { questions } \\
\text { that posed } \\
\text { by friends }\end{array}$ & $0 \%$ & \multirow{3}{*}{$\begin{array}{c}26,0 \\
4 \%\end{array}$} \\
\hline 7 & & $\begin{array}{l}\text { Students do } \\
\text { a given } \\
\text { work }\end{array}$ & $61 \%$ & \\
\hline 8 & & $\begin{array}{l}\text { Students } \\
\text { make notes } \\
\text { of subject } \\
\text { matter }\end{array}$ & $17 \%$ & \\
\hline & $\begin{array}{r}A 1 \\
\text { eliness } S\end{array}$ & $\begin{array}{ll}\text { rage } & \text { of } \\
\text { dents } & \end{array}$ & & \\
\hline
\end{tabular}

1. Comparison of Activeness Students with Cycle I and Cycle II
After doing research, the researchers conducted an analysis of data pertaining to the development of the application of Active Learning Model using Techniques Learning Start With A Question to the increased liveliness of students of class $\mathrm{XI}$ AK 1. The increase is as follows:

Table 4. Comparison of Results liveliness Student Cycle I and Cycle II

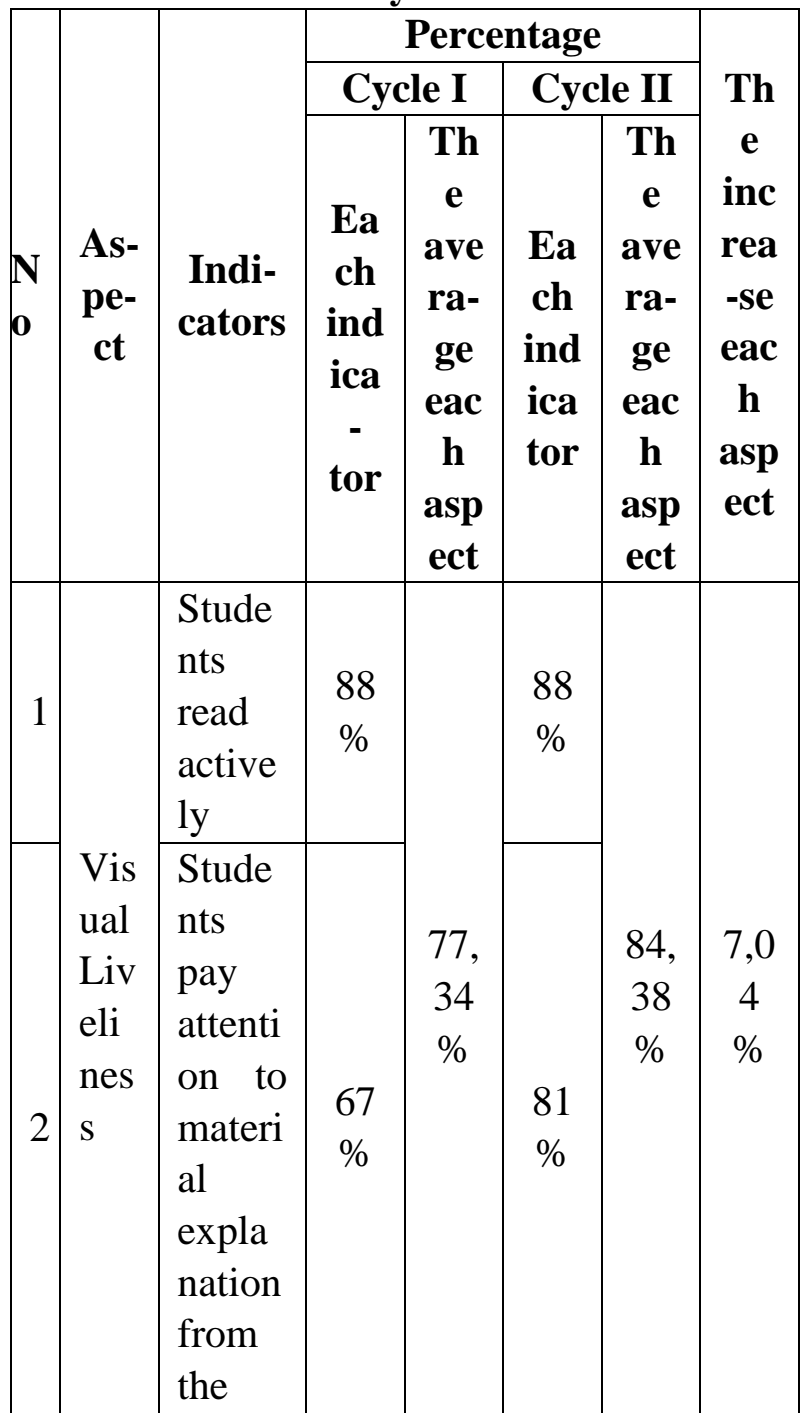




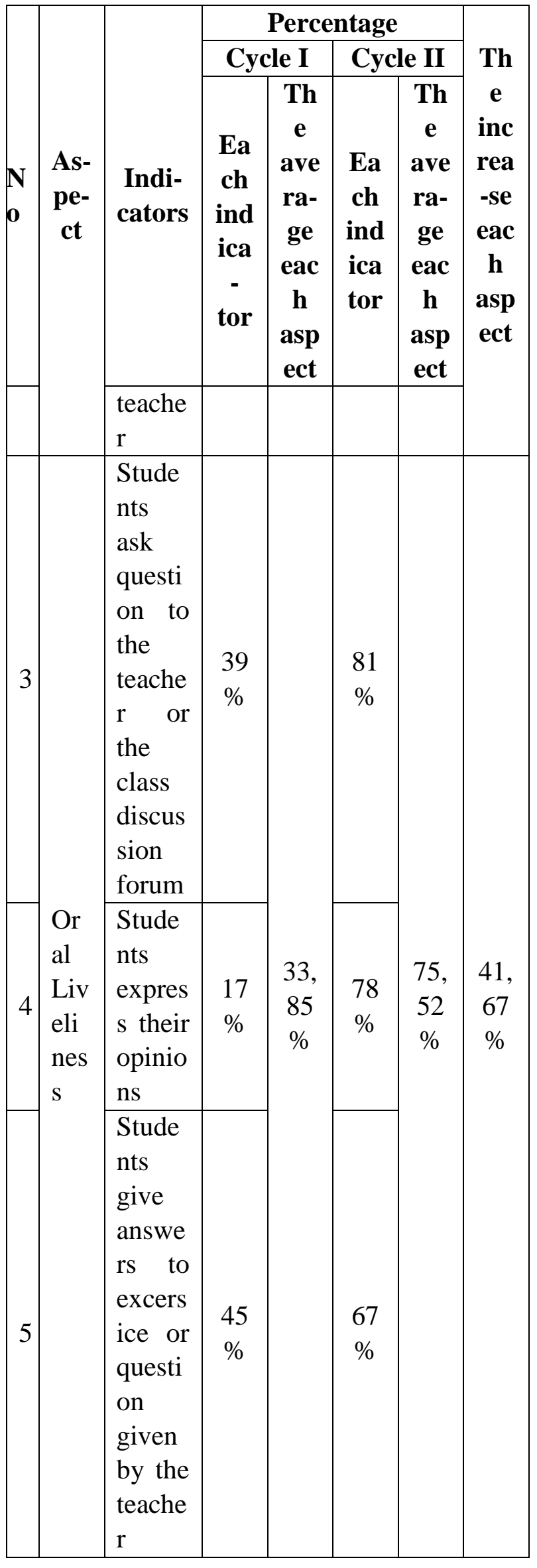

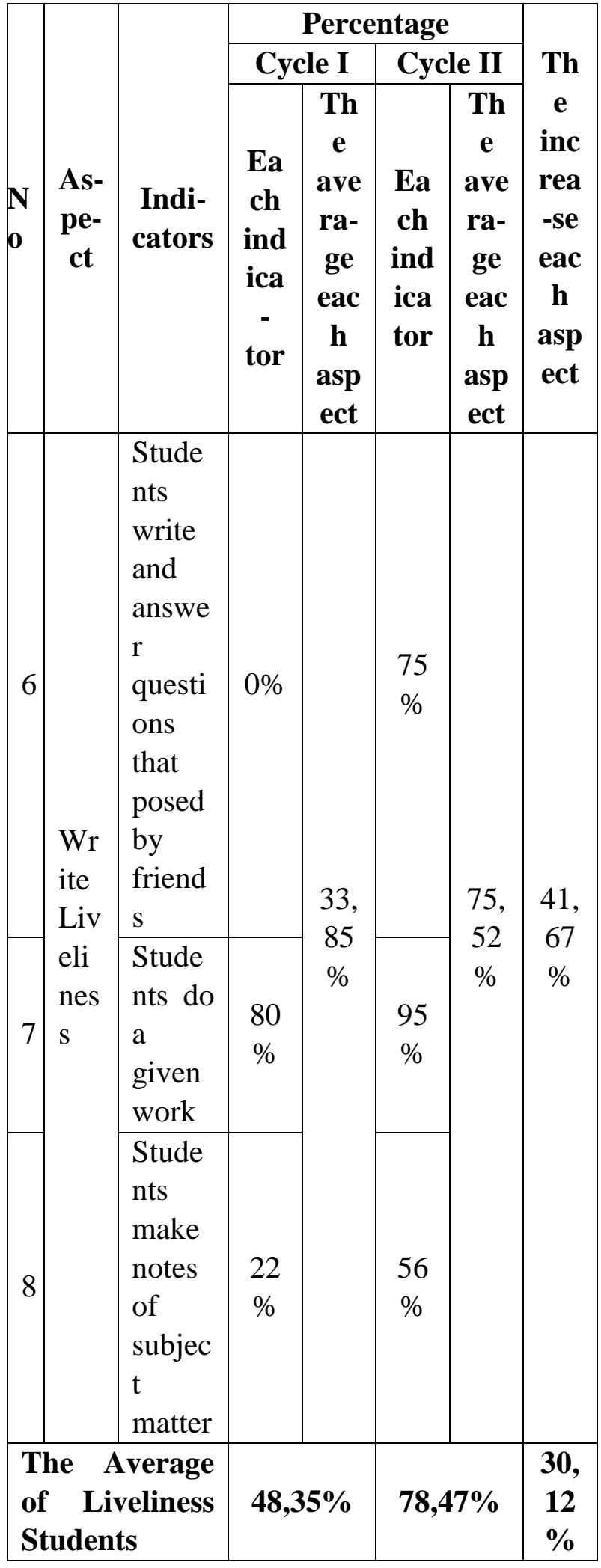

After analyzing the data, it can be seen an increase in the percentage of the three aspects of student activity in learning accounting using Model Active Learning Techniques Learning Start With A Question. 
In the aspect of Visual liveliness shows the results in the first cycle of $77.34 \%$ and the second cycle reach $84.38 \%$, resulting in an increase of $7.04 \%$. The improvement of Visual Liveliness also resulted from an increase in every indicator in that aspect. There are two indicators on aspects of this Visual liveliness, i.e. students actively reading and students consider material explanation of the teacher. The results of the indicator, active students read the first cycle by $88 \%$, while in the second cycle obtain the same results, $88 \%$, although there was no increase, but the achievement percentage of the activity in these indicators has been quite good. Indicator material explanation of the students pays attention to the teacher on the first cycle of $67 \%$, while in the second cycle of $81 \%$, an increase that is pretty good.

The second aspect is the Oral Liveliness in the first cycle results obtained $33.85 \%$, while the second cycle reaches $75.52 \%$. There was an increase high enough in this aspect that is equal to $41.67 \%$. In the aspect of Oral liveliness there are three indicators that made the object of observation, i.e. students are able to express their opinions, students ask questions to the teacher or the class forum, as well as students give answers to practice questions provided by the teacher. Each indicator has increased from the cycle I to cycle II. Indicator of students able to express opinions on the first cycle obtain the results of $17 \%$, while the second cycle obtain the results of $78 \%$. Indicator students ask questions of the teacher or the class forum on the first cycle obtain the results by $39 \%$, while the second cycle of $81 \%$. Indicator students give answers to practice questions provided by the teacher in the first cycle by $45 \%$, while the second cycle of $67 \%$.

The third aspect is Write Liveliness in the first cycle obtain the results by $33.85 \%$, while the second cycle of $75.52 \%$. An increase is quite high anyway that is equal to 41.67\%. In this aspect, there are three indicators that became the object of observation i.e. students write questions and answers asked his friends, students do exercises provided by the teacher and the students make notes learning materials. The third indicator of the whole has increased quite good. Indicator students write questions and answers asked his friends in the first cycle obtain the results of $0 \%$, whereas in the second cycle obtain the results of $75 \%$. Indicator students do exercises provided by the teacher in the first cycle obtain the results by $80 \%$, while in the second cycle of $95 \%$. Indicator students make notes on the subject matter in the first cycle of $22 \%$, while the second cycle of $56 \%$.

The average liveliness of students in the first cycle showed $48.35 \%$ of the students have been active and the average liveliness of students in the second cycle increased to $78.47 \%$. Increased liveliness of learning students from the first cycle to the second cycle of $30.12 \%$. So the indicators of success of $75 \%$ at the liveliness of students of class XI AK 1 has been reached.

The results of the assessment of student learning activeness in the first cycle indicate that there are two aspects or six indicators of students' learning activeness that has not reached the indicators of success of $75 \%$. Based on the results of interviews with students, the students' learning activeness still not optimal, because the students are not familiar with the process of learning that seeks to ask questions. Students still have a sense of reluctant and embarrassed to ask. In addition, because the students also feel shy in expressing his opinion, lack of confidence with the opinions they have.

Based on observations and the results, there are some things that need to be emphasized that the teacher can set the time when learning that the implementation of learning can be optimal and at the time of the initial activity of learning, the teacher guide the students to be more active when the learning activities take place i.e. when to ask questions, express opinions, propose answers to practice questions, write down 
the questions and answers asked his friends, and make a note of the material submitted by teachers. Therefore, researchers and teachers have agreed to conduct the second cycle. In the second cycle of planned improvements to the way teachers guide the students to be more active in learning is when there are still many students who do not ask the teacher will call the names of students to ask questions, as well as when expressing their opinions and answers to practice questions. At the time of the learning activities of teachers also reminded the students to write down questions and answers submitted his friends, as well as recorded material or summaries of material presented at the second cycle.

Based on observations of the second cycle showed an increase in indicator scores of students' learning activeness. Plan improvements that planned in the first cycle can be performed well in the second cycle. This is evident from the data of observation that all three aspects of learning activity of student have achieved the minimum criteria which have been determined on the amount of $75 \%$. In interviews with the students in the second cycle, students have been accustomed in learning to use the Active Learning Model Techniques Learning Start With A Question. Therefore, the discussion of Techniques Learning Start With A Question be solved up with the second cycle.

2. Graphics Improved Student Learning Activeness

Based on the results of students 'learning activeness table in the first cycle and the second cycle can be seen an increase in students' learning activeness. In the first cycle there are two aspects of the activity of students who have not achieved $75 \%$ are aspects of oral liveliness and write liveliness. From these two aspects are almost all the indicators have not reached 75 , resulting in an average of every aspect still low. That's because on the first cycle students are still shy and not accustomed to actively participate in the learning process, especially accounting. While on the second cycle of the three aspects of student activity had reached even exceeded the indicator of success of $75 \%$. In addition, the second cycle almost all indicators of student learning activity has achieved the minimum criteria of $75 \%$. That's because the students in the second cycle have been accustomed in learning to use the Active Learning Model Techniques Learning Start With A Question.

For more details can be seen in the chart students 'learning activeness in the first cycle and the second cycle of the three aspects or eight indicators of students' learning activeness.

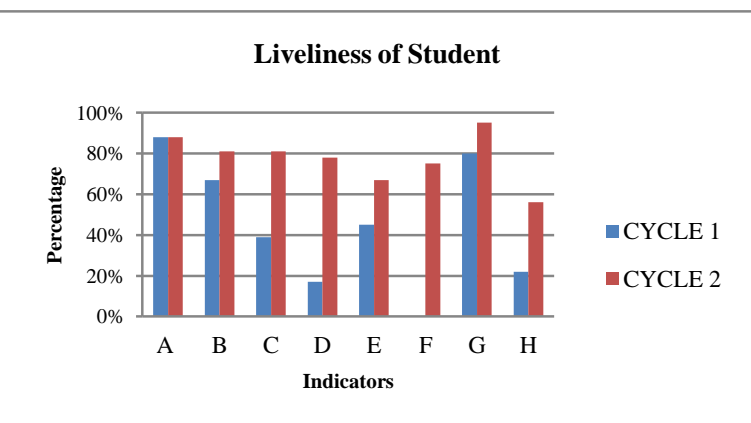

Figure 1. The Graphs Liveliness of Student Each Indicator

Information

A : Students read actively

B : Students pay attention to material explanation from the teacher

C : Students ask question to the teacher or the class discussion forum

D : Students express their opinions

E : Students give answers to excersice or question given by the teacher

F : Students write and answer questions that posed by friends

$\mathrm{G}$ : Students do a given work

$\mathrm{H}$ : Students make notes of subject matter 


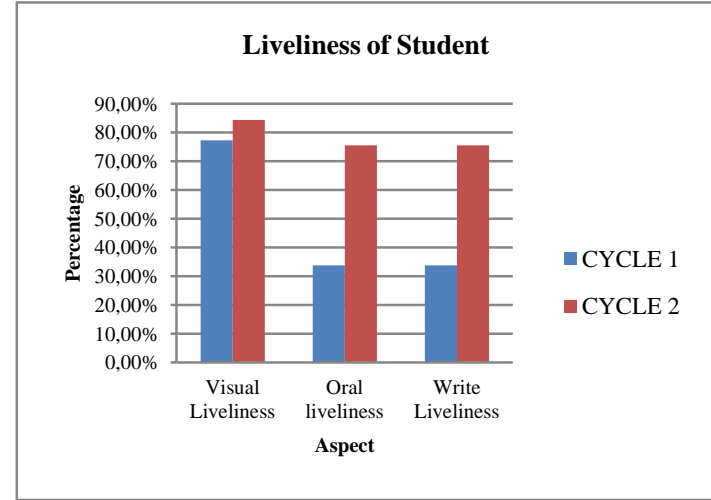

Figure 2. The Graphs Liveliness of Student Each Aspect

All indicators of students' learning activeness can be increased after the implementation of Active Learning Model using Techniques Learning Start With A Question. The increased liveliness of students' learning makes students actively participate in accounting learning activities so that lessons can be accepted easily by the students and in accordance with the purpose of learning.

The results of the study on application of Model Active Learning Techniques Learning Start With A Question accordance with the theory presented Raka Joni (1980: 2) which explains that activity-oriented learning implies that students learning system placing students as active subjects and students who already have a readiness to learn. In view of modern psychology of learning is not just memorize some facts or information, but an experienced mental events and processes. Therefore, any event of learning requires the involvement of the intellectual-emotional students through assimilation and accommodation cognitive to develop knowledge, action and direct experience in order to establish the skills (cognitive, motor, and social), appreciation and internalization of values in the formation of attitudes. In addition, learning that use Active Learning Model Techniques Learning Start With A Question accordance with the theory according to Abu Ahmadi (2004: 212-213), active learning has characteristics that challenge class situation of students for learning activities freely neatly controlled, the teacher does not dominate talks, but many provide a summary of thinking for students to solve problems, teachers provide learning resources for students, student learning activities vary, relationships between teachers and students nature should reflect human relationships like parents and children, the circumstances of the class are not tied to the role of teachers as learning resources and students as passive recipients of information, their courage through questions students ask his opinion or statement of ideas. This was evident in the achievement of students' learning activeness which increased by $30.12 \%$.

The results are consistent with research conducted Elza Firanda Riswandi (2012) entitled " Model Active Learning dengan Teknik Learning Start With A Question untuk Meningkatkan keaktifan Peserta Didik pada Pembelajaran Akuntansi Kelas XI Ilmu Sosial 1 SMA Negeri 7 Yogyakarta Tahun Ajaran 2011/2012" that the Active Learning Model Techniques learning Start with A Question can enhance the activity of students in accounting learning and research conducted by Fitri Umiatun (2013) entitled "Penerapan Model Active Learning Teknik Learning Start With A Question (LSQ) Untuk Meningkatkan Keaktifan Belajar Siswa Pada Pembelajaran Akuntansi Kelas $X$ Akuntansi I SMK Negeri 1 Pengasih Tahun Ajaran 2012/2013" which concluded that the Active learning Model Techniques learning Start With A Question can improve students' learning activeness. The results of this study also support research conducted by Anas Tas Nia Dewi Nur Komaria, Siswandari, Elvia Ivada (2015) entitled "Penerapan Strategi Pembelajaran Aktif Learning Start With A Question Sebagai Upaya Untuk Meningkatkan Keaktifan Peserta Didik Mata Pelajaran Akuntansi Keuangan", shows that through application of active learning strategies Learning Start With A Question can enhance the activity of students of class XI KU 3 SMK Negeri 1 Sukoharjo on financial accounting learning. 
From the discussion, it can be concluded that the model of Active Learning in Techniques Learning Start With A Question can increase liveliness of students. Liveliness due to the application of Active Learning Model Techniques Learning Start With A Question raises their active interaction that occurs between students, teachers, and all components of learning, it can make changes of teacher-centered into students-centered, and from passive students into active student in learning.

\section{CONCLUSIONS AND SUGGESTIONS Conclusions}

Based on the results of research and discussion that has been described, it can be concluded that the application of Active Learning Model using Techniques Learning Start With A Question (LSQ) can increase liveliness of students in accounting learning class XI Accounting 1 SMK Negeri 1 Yogyakarta Academic Year 2016/2017. Increasing liveliness of students seen from the increase in the average percentage of students' learning activeness in accounting learning in the classroom. Improvement liveliness of students can be seen from the average liveliness of students in the first cycle showed $48.35 \%$ of the students have been active and average liveliness of students in the second cycle increased to $78.47 \%$. Increased liveliness of students from the first cycle to the second cycle amounted to $30.12 \%$. So the indicators of success on the involvement of the student class XI AK 1 has been reached.

Increasing liveliness of students can be seen from the three aspects as follows in the aspect of Visual liveliness shows the results in the first cycle of $77.34 \%$ and the second cycle reaches $84.38 \%$, resulting in an increase of $7.04 \%$. The second aspect is Oral liveliness, in the first cycle results obtained $33.85 \%$, while the second cycle reaches $75.52 \%$. There was an increase high enough in this aspect that is equal to $41.67 \%$. The third aspect is Write liveliness, in the first cycle obtain the results by
$33.85 \%$, while the second cycle of $75.52 \%$. An increase is quite high anyway that is equal to $41.67 \%$. Ratings are based on three aspects of each indicator in it.

Liveliness due to the application of Active Learning Model Techniques Learning Start With A Question raises their active interaction that occurs between students, teachers, and all components of learning, it can make changes of teachercentered into students-centered, and from passive students into active student in learning.

\section{Suggestions}

Based on the results of the study, researchers gave the following advice:

For Teachers

a. From these results, oral and write liveliness aspects there are two indicators that are not optimal achievers. The indicator is expressed answers to practice questions provided by the teacher $(67 \%)$ and a record of learning materials were submitted by teachers $(56 \%)$. So expect more teachers can provide feedback to students so that students' enthusiasm and courage in expressing their answers to practice questions provided by the teacher to be more optimal. In addition, more teachers stimulate students about the importance of the notes to the material that has been presented so that students are more motivated to make a note of the material in each of the learning process that takes place.

b. The use of Active Learning model Techniques Learning Start With A Question can be used as an alternative in the learning process accounting. The learning model is expected to provide variety in learning and can increase liveliness of students. 
For Students

a. Students should enhance their liveliness, so they can participate actively during the learning process.

b. Students should boost her confidence in asking questions and express opinions in the learning process.

c. Students should better understand the importance of a record or summary of the learning material that presented by the teachers.

For Further Research

a. For subsequent researchers who will conduct a class action using Active Learning Model Techniques Learning Start With A Question should prepare everything that was needed in the research process is more mature.

b. For future research, should be more careful in the observation process in order to obtain more accurate data.

\section{REFERENCES}

Abu Ahmadi and Widodo Supriyono. (2004). Psikologi Belajar. Jakarta: PT Rineka Cipta.

Arikunto, Suharsimi. (2011). Penelitian Tindakan Kelas. Jakarta: Bumi Aksara.

Badan Standar Nasional Pendidikan. (2010). Paradigma Pendidikan Nasional Abad XXI. Jakarta: BSNP.

Joni, T. Raka. (1980). Strategi BelajarMengajar, Suatu Tinjauan Pengantar, Jakarta.

Riswandi, Elza F. (2012). Model Active Learning dengan Teknik Learning Start With A Question dalam Peningkatan Keaktifan Peserta Didik pada Pembelajaran Akuntansi Kelas XI Ilmu Sosial 1 SMA Negeri 7 Yogyakarta Tahun Ajaran 2011/2012. Jurnal
Pendidikan Akuntansi Indonesia, Vol. X, No. 2, Tahun 2012

Umiatun, Fitri. (2013). Penerapan Model Active Learning Teknik Learning Start With A Question untuk Meningkatkan Keaktifan Belajar Siswa pada Pembelajaran Akuntansi Kelas X Akuntansi 1 SMK Negeri 1 Pengasih Tahun Ajaran 2012/2013.Skripsi Universitas Negeri Yogyakarta.

Komaria, A.T.N, et.al. (2015). Penerapan Strategi Pembelajaran Aktif Learning Start With A Question Sebagai Upaya Untuk Meningkatkan Keaktifan Peserta Didik Mata Pelajaran Akuntansi Keuangan. Jurnal "Tata Arta" UNS, Vol. 1, No. 2, hlm. 223-236. 